Acta vet. scand. $1971,12,572-582$.

From the Department of Microbiology and Immunology, Veterinary College of Norway, Oslo.

\title{
THE PRECIPITATION OF PEPTIDES AND PROTEINS BY LIGNOSULPHONIC ACIDS
}

\author{
By \\ Bjфrn Næss
}

Lignin and lignosulphonic acids are among the main components of sulphite spent liquor, produced in the sulphite process for the manufacture of chemical wood pulp.

The chemical structures of the lignins are not clearly defined, but proposed formulations for lignins have been reviewed by Pearl (1967). Salts of lignosulphonic acids can be precipitated from cold aqueous solution in two main ways, according to Borisek \& Stanic (1958): 1) by reaction with certain inorganic or organic substances, 2) by separation of the lignosulphonic acid molecules from the hydrate shell, and precipitation with respect to the colloid nature of the liquor.

The lignosulphonic acids react with certain proteins to form camplexes, and this reaction has been utilized by Jantzen (1969), for the separation and isolation of certain lignosulphonic acids in sulphite spent liquors. The reaction is also used in tanning hides to leather (Reich 1967) and in removing contaminating proteins from the effluents of canneries and fish-processing plants (Pearl 1957) and from slaughter-houses (Tønseth \& Berridge 1968, Jorgensen 1971). Sieber (1951) described the precipitation of gelatin, in $\mathrm{NaCl}-$ solution by lignosulphonic acids, as a characteristic qualitative reaction of sulphite spent liquor. 
The aim of the present work was to study the precipitation of various peptides and proteins with sulphite spent liquor and with isolated lignosulphonic acids.

\section{MATERIALS AND METHODS}

Sulphite spent liquor. A fermented liquor from an alcohol distillery was used. The analytical data of the liquor were as follows: Dry basis $8.5 \%$; sugars $1.5 \%$ and $\mathrm{pH}$ 5.1. This liquor is referred to as crude sulphite spent liquor. Dialysed liquor was also used with dialysis being carried out against running tap water for $15 \mathrm{hrs}$. The liquors were stored at $-20^{\circ} \mathrm{C}$.

Lignosulphonic acids. Sulphite spent liquor was treated with $\mathrm{CaO}\left(1.5 \mathrm{~g} \mathrm{CaO}\right.$ per $100 \mathrm{ml}$ of sulphite spent liquor) at $40^{\circ} \mathrm{C}$. The precipitate was centrifuged and washed twice with distilled water, after which the upper homogenous layer of the centrifuged precipitate was collected, dissolved in $0.01 \mathrm{M}-\mathrm{HCl}$, and $0.1 \mathrm{M}$ $\mathrm{NaOH}$ added to pH 6.8. The solution was dialysed against running tap water for $15 \mathrm{hrs}$. in order to remove low molecular weight saccharinic acids and saccharates, and small free cations and anions according to the precipitation theory of Hall (1956). Low molecular weight lignosulphonic acids are also supposed to be lost during dialysis. Only traces of oxalic acid-precipitable substances could be identified after dialysis. The purified material was freeze-dried and stored in a desiccator at room temperature, and solutions to be used prepared when needed. These lignosulphonic acids are referred to as isolated lignosulphonic acids.

Agar gel. For experiments performed on agar plates $1.15 \%$ Bacto-agar (Difco* 0140-01) was used as basis. Thimerosal was added (final concentration $0.01 \%$ ) as microbicidal agent. The addition of thimerosal was found to have no influence on the experiments carried out on the agar plates.

Preparation of peptide-and protein-agar plates. One of the following peptides or proteins was added to the melted agar at $70-80^{\circ} \mathrm{C}$, to a final concentration of 1,2 or $3 \%$ : Sodium caseinate (Eastman Kodak ${ }^{\star \star}$ ), neopeptone (Difco 0119-01), proteosepeptone (Difco 0120-01), gelatin $\left(\right.$ Gelita $\left.^{\star \star \star}\right)$, or a number of

* Difco Laboratories Inc., Detroit, USA.

* * Eastman Kodak, New York, USA.

* * Gelita, Göppingen, Germany. 
dipeptides $^{\star}\left(\right.$ Sigma $\left.^{\star \star}\right)$. The hot mixture was then poured into horizontally placed Petri dishes to a thickness of $1.5 \mathrm{~mm}$. Agar plates containing serum were prepared by adding horse serum to a concentration of 5 or $10 \%(\mathrm{v} / \mathrm{v})$. Agar plates, with various $\mathrm{pH}$ values, were prepared for each type of peptide and protein in the range $\mathrm{pH} 4-8$, by adding $1 \mathrm{M}-\mathrm{HCl}$ or $1 \mathrm{M}-\mathrm{NaOH}$. A $2 \%$ neopeptone agar plate with dialysed peptides and $\mathrm{pH} 6.2$ was also prepared, the dialysis carried out against running tap water for $15 \mathrm{hrs}$.

Circular wells of $7 \mathrm{~mm}$ diameter were cut in the solid agar with a cork borer, and $50 \mu \mathrm{l}$ of the lignosulphonic acid-containing solutions to be tested were applied into the wells.

Isoelectric points. The isoelectric points of the peptides were determined by studying the migration of the peptides in agar gel electrophoresis. The agar gels were prepared as $1 \%$ agar (Difco, Special Noble agar, 0142-01) in 0.05 M Tris-HCl buffers, the $\mathrm{pH}$ being varied from 6.6 to 8.0. The same buffers were also used as running buffers. The peptide solution $(7 \%)$ was applied in circular wells ( $2.5 \mathrm{~mm}$ diameter) in agar gel on microscope slides, and the electrophoresis carried out with LKB $\dagger$ equipment for gel electrophoresis. The running time was $60 \mathrm{~min}$. at $300 \mathrm{v}$.

Developing system. For identifying the low molecular weight peptides after electrophoresis, a longitudinal ditch was cut in the agar gel and filled with ninhydrin in methoxyl ethanol solution $(2 \%)$. The slides were then incubated at $50^{\circ} \mathrm{C}$ for $2 \mathrm{hrs}$., the peptides being stained bluish-red by the ninhydrin. High molecular weight peptides were identified by drying parallel slides at room temperature overnight and staining with $1 \%$ amido black $10 \mathrm{~B}$ (Merck $\dagger \dagger$ ) in $7 \%$ acetic acid followed by differentiating with $7 \%$ acetic acid.

Spectrophotometric measurements. The turbidity caused by peptide- or protein-lignosulphonic acid complexes in agar gel was

* DL-alanyl-DL-serine, DL-alanyl-DL-phenylalanine, L-alanyl-Lhistidine, glycyl-L-methionine, glycyl-L-asparagine, glycyl-L-aspartic acid, L-valyl-L-leucine, glycyl-L-isoleucine, glycyl-L-proline, glycyl-Lalanine, N-glycyl-L-serine, DL-alanyl-DL-asparagine, DL-alanyl-DLalanine, DL-leucylglycine, L-valylglycine, L-leucyl-L-serine.

* * Sigma Chemical Company, St. Louis, Missouri, USA.

$\dagger$ LKB Instruments, Ltd., Stockholm, Sweden.

$\dagger \dagger$ Merck, Darmstadt, Germany. 
measured at room temperature in a "Hilger"* spectrophotometer at $700 \mathrm{~nm}$ after mixing the reagents in melted agar at $70-80^{\circ} \mathrm{C}$ in standard test tubes and allowing the solution to solidify. Precipitation experiments in solution, in the absence of agar, were also carried out in standard test tubes and the turbidity measured as described.

Chemicals. The chemicals used-were of analytical grade.

\section{RESULTS}

Isolated lignosulphonic acids, dialysed sulphite spent liquor and crude sulphite spent liquor, were separately applied into different wells in agar plates holding various $\mathrm{pH}$ values, and containing various concentrations of sodium caseinate, horse serum, neopeptone, proteosepeptone, gelatin or a number of dipeptides. After $15-30 \mathrm{~min}$. at $25^{\circ} \mathrm{C}$, distinct, circular yellowgrey or greyish-white precipitation zones appeared around the wells on neopeptone-, proteosepeptone-, gelatin-, caseinate- and serum-containing agar plates, primarily on most acid plates. Neopeptone resulted in the most distinct precipitation zones around the wells containing isolated lignosulphonic acids or dialysed sulphite spent liquor (Fig. 1). In order to obtain distinct precipitation zones, $2 \%$ neopeptone in the agar was found suitable. Dialysis of the neopeptone before preparing the agar plate did not prevent the occurrence of precipitation zones.

When the diameter of the zones exceeded about $12 \mathrm{~mm}$, in $2 \%$ neopeptone agar plates, within $24 \mathrm{hrs}$. at $25^{\circ} \mathrm{C}$, central zones of lysis appeared. Heating of the lignosulphonic acid solution to $100^{\circ} \mathrm{C}$ for $10 \mathrm{~min}$. before application had no effect on the occurrence of zones of lysis.

When crude sulphite spent liquor was used, sodium caseinate agar plates gave the most distinct precipitation zones. The precipitating activity in this system was, however, reduced, after heating the sulphite spent liquor to $100^{\circ} \mathrm{C}$ for $10 \mathrm{~min}$. before applying it into the agar wells. The remaining activity was, in addition, considerably reduced after dialysis. The $\mathrm{Ca}^{++}$content in the crude sulphite spent liquor was found to be considerable.

The dipeptides tested did not result in precipitation zones in the $\mathrm{pH}$. region $4.0-7.5$.

Fig. 2 shows precipitation zones caused by a serial 2-fold

* Hilger \& Watts, Rank Precision Industries Ltd., London, England. 


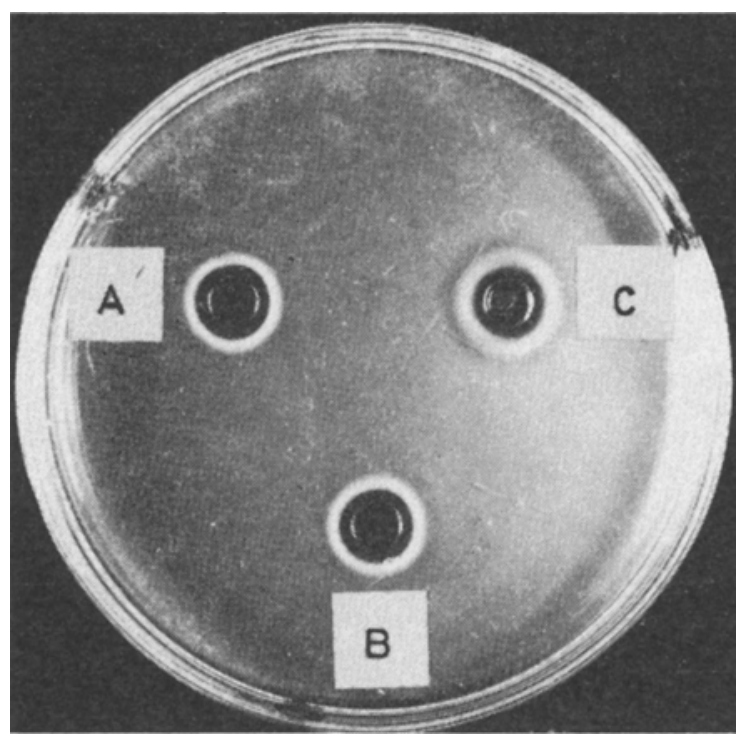

Figure 1. Precipitation zones caused by $50 \mu 12 \%$ isolated lignosulphonic acids (A), $50 \mu 1$ dialysed sulphite spent liquor (B) and $50 \mu 1$ crude sulphite spent liquor $(\mathrm{C})$, in an agar plate containing $2 \%$ neopeptone. $\mathrm{pH}$ in the agar and liquors 6.8. Incubation time $5 \mathrm{hrs}$. at $25^{\circ} \mathrm{C}$.

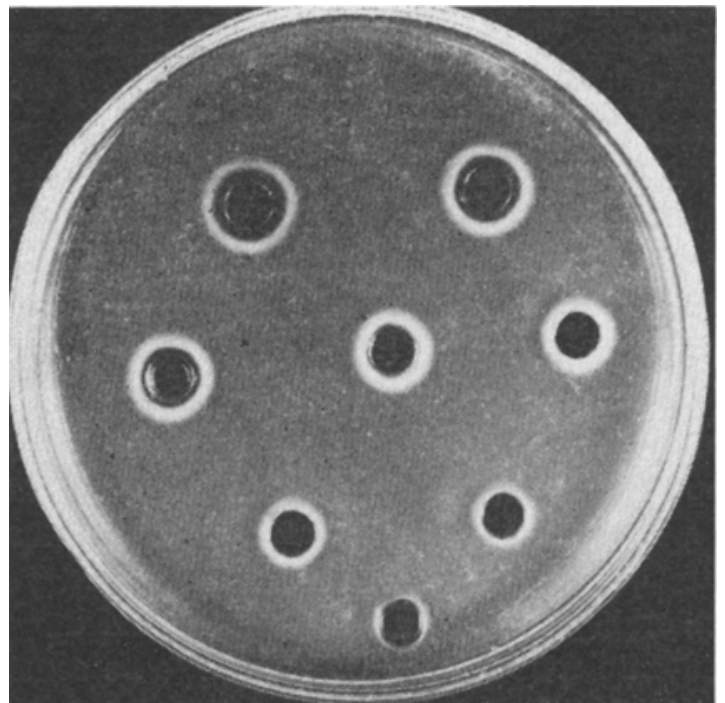

Figure 2. Precipitations zones caused by transferring aliquots of $50 \mu 1$ of 2-fold serial dilutions of crude sulphite spent liquor to wells in an agar plate containing $2 \%$ neopeptone, $\mathrm{pH} 6.8$. The dilutions are from left to right in each row: 1/1, 1/2, 1/4, 1/8, 1/16, 1/32, 1/64 and 1/128. The incubation time was $4 \mathrm{hrs}$. at $25^{\circ} \mathrm{C}$. 
dilution of crude sulphite spent liquor in a neopeptone agar plate. As can be seen, the diameters of the zones are dependent on the concentrations of the lignosulphonic acids. The relation between the diameters of the precipitation zones and the incubation time, at various incubation temperatures, is shown in Fig. 3. It can be

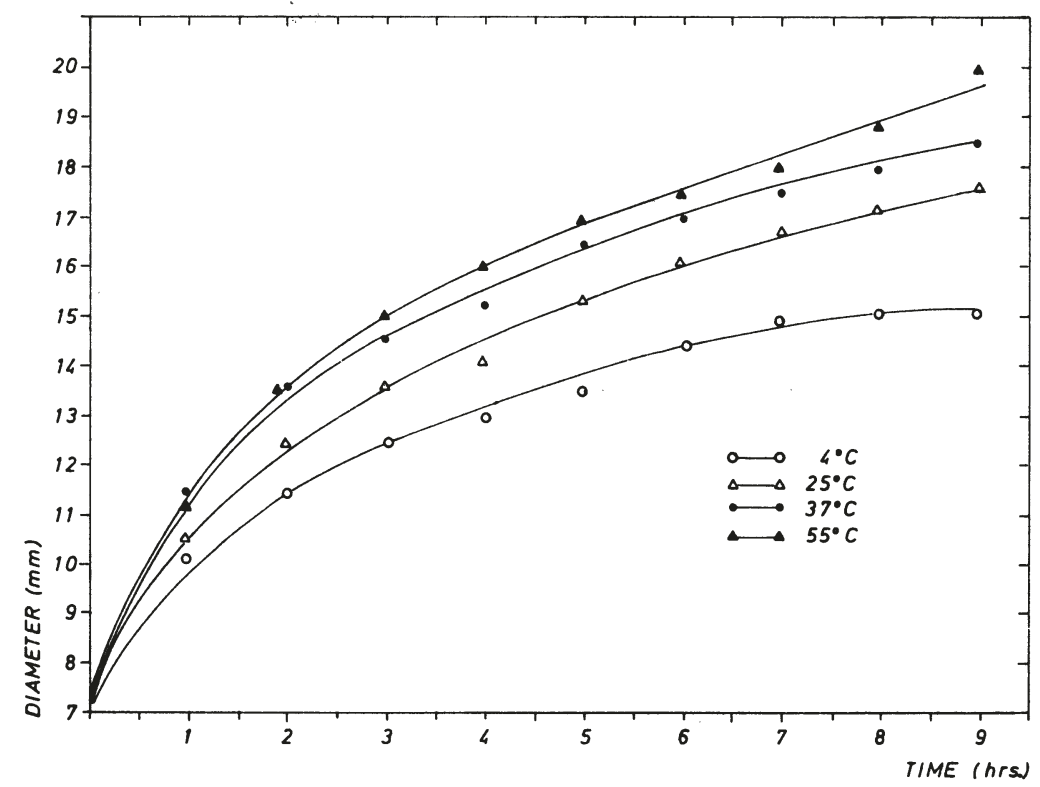

Figure 3. Diameters of precipitation zones in agar plates containing $2 \%$ neopeptone, caused by $50 \mu l$ crude sulphite spent liquor, measured as a function of time. $\mathrm{pH}$ in agar and liquors 6.8.

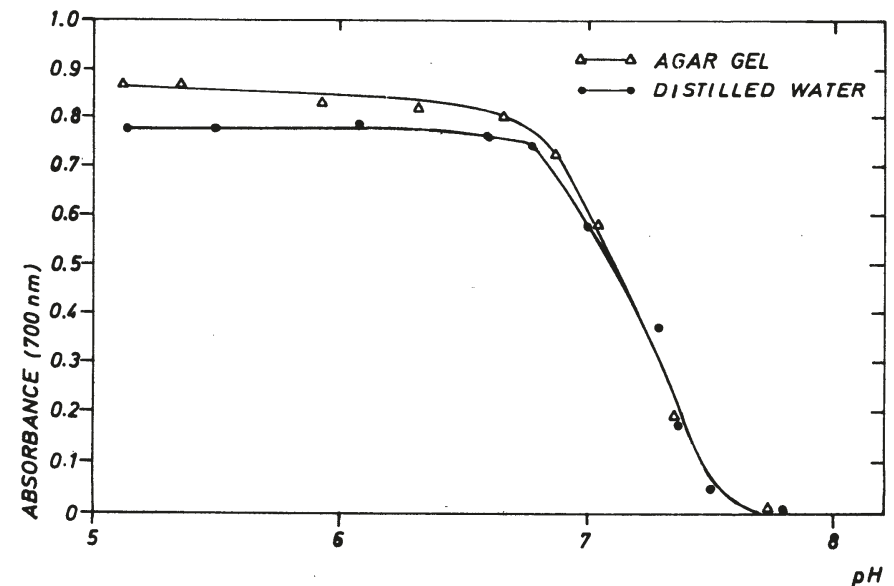

Figure 4. Effect of $\mathrm{pH}$ on the formation of precipitates in a mixture of lignosulphonic acids and peptides in distilled water, and in solid agar gel, measured spectrophotometrically. Reaction mixture: $2.0 \mathrm{ml}$ distilled water or agar $(1.4 \%)$ containing $2 \%$ neopeptone, and $0.2 \mathrm{ml}$ dialysed sulphite spent liquor. 
seen that when the plates were incubated at $4{ }^{\circ} \mathrm{C}, 25^{\circ} \mathrm{C}, 37^{\circ} \mathrm{C}$ and $50^{\circ} \mathrm{C}$ respectively, the zones of precipitation increased with increasing temperature, provided that the other conditions were constant. The diameters increased gradually for incubation periods up to $24 \mathrm{hrs}$. at $25^{\circ} \mathrm{C}$ and the border of the zones remained quite distinct. Further incubation resulted in steadily increasing diameters, but the borders of the zones became gradually indistinct. The turbidity caused by peptide-lignosulphonic acid precipitates in solid agar gel and in distilled water was measured as absorbance at $700 \mathrm{~nm}$ and is plotted against $\mathrm{pH}$ (Fig. 4). The figure shows that the precipitation is strictly dependant on $\mathrm{pH}$. An essentially similar $\mathrm{pH}$ dependency was found with, and without, agar in the reaction mixture. In order to obtain significant precipitation, the $\mathrm{pH}$ of the neopeptone agar plates was, therefore, in later experiments, adjusted to 6.8 , the highest value giving maximum precipitation.

Precipitates of peptide- and protein-lignosulphonic acid complexes were found to be readily soluble in dilute $\mathrm{NaOH}$, and insoluble in dilute $\mathrm{HCl}$.

In Figs. 5 and 6 the turbidity caused by peptide-lignosulphonic acid complexes in distilled water and in solid agar gel is shown as a function of the lignosulphonic acid and peptide concentration respectively. It can be seen that the dependency curves have essentially similar shapes when the reaction mixtures contain, and do

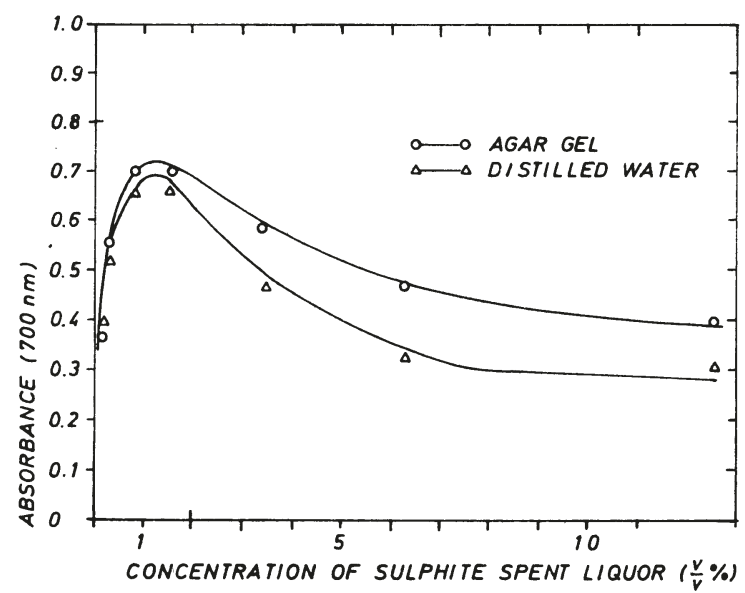

Figur e 5. Absorbance caused by peptide-lignosulphonic acid precipitates in distilled water, and in solid agar gel $(0.7 \%)$ as a function of the crude sulphite spent liquor concentration in an $0.5 \%$ neopeptone solution. $\mathrm{pH}$ in the mixture 6.8. 


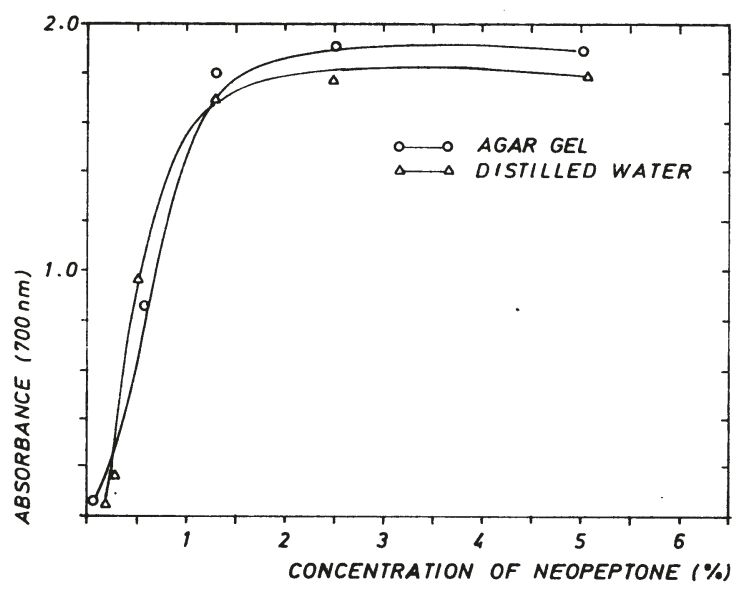

F i g u r e 6. Absorbance caused by peptide-lignosulphonic acid precipitates in distilled water, and in solid agar gel $(0.7 \%)$, as a function of peptide concentration in an $0.3 \%(\mathrm{v} / \mathrm{v})$ solution of crude sulphite spent liquor. $\mathrm{pH}$ in the mixture 6.8 .

not contain, agar. A relationship similar to that shown in Fig. 5, was found when isolated lignosulphonic acids were substituted for sulphite spent liquor in the reaction mixtures.

Isoelectric points for peptides in neopeptone were found to vary between $\mathrm{pH} 7.0$ and 7.5 .

Application of lignosulphonic acids into wells in agar plates not containing peptides or proteins, did not result in any zones of precipitation.

\section{DISCUSSION}

The agar did not seem to participate in the chemical reactions in these experiments, as similar results were obtained in solid agar-containing and liquid agar-free reaction mixtures. Thus peptide- and protein-containing agar plates were found suitable for the demonstration of, and studies on, the formation of peptide- and protein-lignosulphonic acid precipitates, and on reactions with other components of sulphite spent liquor. Except for dipeptides, precipitation zones were obtained with all the peptides and proteins tested. This result indicates that the peptides have to exceed a minimum molecular size in order to form precipitates with lignosulphonic acids.

Central lysis in the precipitation zones occurred only around the wells containing the most concentrated lignosulphonic acid 
solutions (Fig. 2). Due to the thermostability of the lysis-forming components, the lysis zones do not seem to be caused by proteolytic enzymes possibly present in the liquors. It can be seen from Fig. 5 that excess of sulphite spent liquor in a peptide solution, inhibits the formation of peptide-lignosulphonic acid precipitates. This could be the explanation for the appearance of lysis zones in the peptide-lignosulphonic acid precipitation zones in the agar plates.

The temperature labile precipitating components of crude sulphite spent liquor which were found after application of the liquor into wells in caseinate agar plates, are assumed to be casein-precipitating enzymes (Sandvik 1962). As the $\mathrm{Ca}^{++}$content in the crude sulphite spent liquor was found to be considerable, this may be among the dialysable components which influence the caseinate precipitation.

Borišek \& Stanic (1958) regarded lignosulphonic acid as a molecular colloid with a negative charge due to the $-\mathrm{SO}_{3} \mathrm{H}$ groups and with a hydrate shell. Precipitation of this system may occur when the molecule is separated from the hydrate shell and the negative charge is neutralized. The conclusions of Borišek \& Stanic were based on studies of the effect of lower alcohols and certain salts on lignosulphonic acids. It can be seen from Fig. 4 that in order to obtain precipitation in the presence of neopeptone and lignosulphonic acids, the $\mathrm{pH}$ in the solutions has to be below 7.5. The effect of $\mathrm{pH}$ on the precipitation considered in relation to isoelectric points of the peptides, as found in this work, seems to support the precipitation theory of Borišek \& Stanic. A possible explanation of the precipitation of peptides and proteins by lignosulphonic acids may be: Parts of the peptides may form hydrogen bonds with the molecular colloid surface and thus have a separating effect on the hydrate shell, and positively charged amino-groups may neutralize negatively charged sulpho-groups. Another explanation may be: Parts of the peptides may form hydrogen bonds with the molecular colloid surface, and negatively charged carboxyl-groups may be linked to negatively charged sulpho-groups by bivalent metallic ions. The latter theory seems unlikely, however, as dialysis of the sulphite spent liquor and peptide solutions did not prevent the peptide-lignosulphonic acid precipitation and no significant oxalic acid-precipitate could be detected after dialysis. A theory based on work with collagen, as reviewed by Reich (1967), states 
that the protein-lignosulphonic acid bond is primarily of electrostatic nature, but that hydrogen bonds may occur from hydroxyl groups in the lignosulphonic acid molecule to the peptides.

The effect of the incubation temperature and the initial concentration of lignosulphonic acids upon the formation of precipitation zones in agar, is in agreement with the general findings on diffusion of substances in agar gel (Crowle 1961).

Studies on the precipitating ability of lignosulphonic acids on peptides and proteins, are important in order to explain the chemical reactions which occur when sulphite spent liquors are released into fiord basins and rivers. Similar studies may also elucidate what happens in the liquor when sulphite spent liquors are used as substrates for microbial protein production (single cell protein production).

As the zone diameters seem to be dependent on the concentration of the lignosulphonic acids, the described agar diffusion method could possibly be developed as a direct micro quantitative procedure for the determination of peptide-precipitating lignosulphonic acids in aqueous solution.

\section{ACKNOWLEDGEMENT}

The sulphite spent liquors used in this work were kindly supplied by $A / S$ Tofte Cellulosefabrik, Hurum, Norway.

\section{REFERENCES}

Borišek, R. \& V. Stanic: The precipitation of sulphite spent liquors by means of metal hydroxides: Theory and practice. Tappi 1958, $5,188-194$.

Crowle, A. J.: Immunodiffusion. Academic Press, New York and London 1961, 23-26.

Hall, L.: Sulfitavlutens tekniska användning. (Technical uses of sulphite spent liquor). Svensk Pappers-Tidn. 1956, 59, 716-720.

Jantzen, L.: Personal communication, 1969.

Jørgensen, $S$. E.: Precipitation of proteins in waste water. Vatten 1971, 1, 58-72.

Pearl, I. A.: Present status of chemical utilization of lignin. Forest Prod. J. 1957, 12, 427-432.

Pearl, I. A.: The Chemistry of Lignin. Marcel Decker Inc., New York 1967.

Reich, G.: Gerbstoffe. (Tanning substances). In Verwertungsgebiete für Sulfitablauge. (Applications of sulphite spent liquor). Ed. F. Melms \& K. Schwenzon. VEB Deutscher Verlag für Grundstoffindustrie, Leipzig 1967, 280—288. 
Sandvik, O.: Studies on casein precipitating enzymes of aerobic and facultatively anaerobic bacteria. Thesis. Veterinary College of Norway, Oslo 1962.

Sieber, R.: Die chemisch-technischen Untersuchungs-Methoden der Zellstoff- und Papier-Industrie. (The chemical and technical analysis methods of the chemical pulp and paper industry). Springer Verlag Berlin 1951, 327-328.

Tфnseth, E. J. \& H. B. Berridge: Removal of proteins from industrial waste waters. Effl. Water Treatm. J. 1968, 8, 124-128.

\section{SUMMARY}

The precipitation of peptide- and protein-lignosulphonic acid complexes can be demonstrated and studied in agar plates in the form of precipitation zones. The effects on the precipitates caused by variations in incubation temperature, incubation time, concentration of the reagents and in $\mathrm{pH}$ in the mixture of reagents, are described, and the nature of the peptide-lignosulphonic acid bond is discussed. The central lysis zones which appeared in some precipitation zones were found to be probably caused by excess of lignosulphonic acids. The possibility of developing the agar precipitation method described as a direct micro quantitative procedure for the determination of certain lignosulphonic acids in aqueous solution is suggested.

\section{SAMMENDRAG}

Presipitering av peptider og proteiner med ligninsulfonsyrer.

Det har vist seg mulig å demonstrere og studere presipitering av peptider og proteiner med ligninsulfonsyrer $i$ form av presipiteringssoner i agarplater. En har beskrevet virkningen på presipitatet av variasjon $i$ inkuberingstemperatur, inkuberingstid, konsentrasjon av reagenter og $\mathrm{pH} i$ blandingen av reagenter, og en har diskutert bindingen i peptid-ligninsulfonsyre-komplekset. Lysissonene som ble utviklet sentralt i noen presipiteringssoner, er trolig forårsaket av overskudd av ligninsulfonsyrer. Muligheten for å utvikle den beskrevne agar-presipiteringsmetode som en direkte mikro-kvantitativ metode for å bestemme visse ligninsulfonsyrer i vandig løsning er antydet.

(Received November 28, 1970). 